\title{
HUBUNGAN TINGKAT PENGETAHUAN \\ DAN PERILAKU MAHASISWA TENTANG \\ PEMBERANTASAN SARANG NYAMUK (PSN) \\ DEMAM BERDARAH DENGUE (DBD) TERHADAP \\ KEBERADAAN JENTIK AEDES AEGYPTI
}

\author{
THE CORRELATION BETWEEN EDUCATIONAL LEVEL AND BEHAVIOUR OF \\ UNIVERSITY STUDENT ABOUT MOSQUITO NEST ERADICATION (PSN) OF \\ DENGUE HAEMORRHAGIC FEVER (DHF) TOWARD LARVAE AEDES AEGYPTI
}

\author{
Rochmadina Suci Bestari, Purnama Parulian Siahaan \\ Program Studi Pendidikan Dokter, Fakultas Kedokteran \\ Universitas Muhammadiyah Surakarta \\ Korespondensi: dr. Rochmadina Suci Bestari, M. Sc. Email: rsb156@ums.id
}

\begin{abstract}
ABSTRAK
Metode Pemberantasan Sarang Nyamuk (PSN) 3M merupakan cara yang mudah dan murah untuk dilakukan akan tetapi kenyataannya cara ini tidak terlaksana dengan baik. Hal ini sangat erat dengan kebiasaan hidup bersih dan pemahaman serta perlakuan terhadap bahaya DBD. Penelitian ini bertujuan untuk mengetahui adanya hubungan tingkat pengetahuan dan perilaku mahasiswa tentang PSN DBD terhadap keberadaan jentik Aedes aegypti di Desa Karang Asem Kecamatan Laweyan Kota Surakarta. Penelitian ini termasuk observasional analitik non eksperimen dengan pendekatan cross sectional, pengambilan sampel dengan purposive sampling sejumlah 43 responden. Data diperoleh dari data primer dengan kuesioner dan uji pemeriksaan larva. Analisis statistitik menggunakan Uji spearman. Hasil penelitian secara statistik dengan uji spearman didapatkan bahwa tidak ada hubungan tingkat pengetahuan tentang PSN DBD terhadap keberadaan jentik Aedes aegypti dengan nilai $\rho=0,464(\rho>0.05)$ dan terdapat hubungan antara tingkat perilaku PSN DBD terhadap keberadaan jentik Aedes aegypti. tingkat pengetahuan PSN DBD tidak terdapat hubungan terhadap keberadaan jentik Aedes aegypti dan terdapat hubungan tingkat perilaku PSN DBD terhadapat keberadaan jentik nyamuk Aedes aegypti.
\end{abstract}

Kata Kunci: Tingkat Pengetahuan PSN DBD, tingkat perilaku PSN DBD, keberadaan jentik Aedes aegypti

\section{ABSTRACT}

Mosquito nest eradication (PSN) is an easy and inexpensive method to do but in reality this does not done properly. This failure caused by the poor habits of cleanliness, the understanding and treatment of the dangers of dengue fever (DBD). This study aims to determine the relationship between the level of knowledge and behavior of students on PSN DBD to the presence of Aedes aegypti larvae in the village of Karang Asem Laweyan District of Surakarta. this study included non-experimental observational analytic with cross sectional approach, sampling taken by purposive sampling on 43 respondents. Data obtained from primary data by questionnaire and single larva examination. The statistic was analyzed by spearman test. The Results of the study were statistically with spearman test showed that there is no relationship between the level of knowledge of PSN DBD to the presence of Aedes aegypti larvae with the value of $\rho=0.464$ and in behavioral level, there is a relationship between PSN DBD and the presence of Aedes aegypti mosquito larva with the value of $\rho=0.023$. The conclusion from this study that there is no relationship between the level of knowledge of PSN DBD to the presence of Aedes aegypti larvae and in behavioral level, there is a relationship between PSN DBD and the presence of Aedes aegypti mosquito larva.

Keyword: knowledge level of PSN DBD, behavior PSN DBD, presence of larva Aedes aegypti 


\section{PENDAHULUAN}

Sebagian besar wilayah tropis dan subtropis sering ditemukan penyakit Demam Berdarah Dengue (DBD), terutama Asia Tenggara, Amerika Tengah, dan Karibia. Manusia adalah host DBD serta virus dengue dengan kategori famili Flaviridae dan genus Flavivirus sebagai agent. Media perantara virus dengue menuju host manusia yaitu melalui vektor nyamuk yang sudah terinfeksi, antara lain nyamuk Aedes aegypti dan Aedes albopictus (Chen et al., 2006). World Health Organization atau WHO menyimpulkan bahwa insiden terjadinya DBD di dunia mengalami perkembangan yang sangat pesat karena diperkirakan 390 juta terinfeksi oleh virus dengue per tahun. Kasus di Amerika, Asia Tenggara, dan Pasifik Barat diperkirakan lebih dari 3,2 juta terjangkit DBD pada tahun 2015 (WHO, 2016).

Indonesia merupakan salah satu wilayah endemik terhadap insiden DBD (Chen et al., 2006). Kemenkes menyatakan pada pertengahan bulan Desember di tahun 2012 terdapat 90.245 orang menderita DBD, sedangkan 816 jiwa meninggal dunia (KEMENKES, Profil Kesehatan Indonesia, 2012). Penyakit DBD di provinsi Jawa Tengah adalah suatu permasalahan serius, pada tahun 2012 angka kesakitan ataupun Incidence rate (IR) yang terjadi di Jawa Tengah sebesar 19,29/100.000 penduduk, angka kesakitan ini meningkat dibandingkan tahun 2011 (DINKES, Buku Profil Kesehatan Jawa Tengah, 2012). Setiap tahun terjadi peningkatan dalam kasus Demam berdarah Dengue yang ada kaitannya dengan faktor lingkungan dengan sanitasi buruk sehingga terbentuknya sarang bagi nyamuk betina berkembang biak seperti bejana yang berisi air, kaleng bekas, bak mandi, dan tempat penampungan air lainnya (Chen et al., 2006). Metode preventif untuk tata laksana DBD yang dianjurkan oleh Kementerian Kesehatan dan juga sebagai pengendalian penyakit DBD yang telah diatur dalam KEPMENKES nomor 582/ MENKES/SK/VII/1992 yaitu dengan metode pemberantasan sarang nyamuk (PSN) DBD dengan tujuan memperkuat surveilans epidemiologi dan pencegahan kejadian luar biasa DBD. Walaupun metode pemberantasan sarang nyamuk 3M merupakan cara yang mudah akan tetapi kenyataannya cara ini tidak terlaksana dengan baik. Ini sangat erat dengan kebiasaan hidup bersih dan pemahaman serta perlakuan terhadap bahayanya DBD (KEMENKES, Petunjuk Teknis Pemberantasan Sarang Nyamuk Demam Berdarah Dengue ( PSN DBD) oleh juru pemantau jentik (Jumantik), 2012; Suharti, 2010)

Sebelum melakukan tahap PSN DBD atau pengontrolan larva yang harus dilakukan dalam tindakan awal yaitu dengan survei jentik nyamuk, salah satunya dengan metode visual (KEMENKES, Modul Pengendalian Demam Berdarah Dengue, 2011). Berdasarkan uraian di atas serta dengan kegiatan dan data penelitian yang sudah ada membahas tentang tingkat pengetahuan dan perilaku terhadap PSN DBD, maka penulis tertarik melakukan penelitian untuk mengetahui tentang "apakah ada hubungan tingkat pengetahuan dan perilaku mahasiswa tentang PSN DBD terhadap keberadaan jentik di Desa Karang Asem Kecamatan Laweyan Kota Surakarta”. Peneliti memilih daerah Desa Karang Asem Kecamatan Laweyan Kota Surakarta, daerah tersebut mempunyai faktor risiko yang tinggi terjadinya DBD karena berada di dekat kampus perkuliahan ATMI sehingga sebagian besar didominasi oleh mahasiswa ATMI tersebut, serta peran mahasiswa sendiri sebagai agent of change bagi lingkungan sekitar, faktor risiko yang menyebabkan DBD lainnya yaitu faktor lingkungan yang terdiri dari kepadatan rumah dalam suatu permukiman, adanya tempat perindukan nyamuk, curah hujan di mana efek pemanasan global yang menyebabkan perkembangbiakan vektor nyamuk DBD menjadi tinggi (KEMENKES, Demam Berdarah Dengue, 2010).

\section{METODE}

Desain Penelitian menggunakan observasional analitik dengan pendekatan cross sectional. Penelitian ini dilakukan di Desa Karang Asem, Kecamatan Laweyan, Kota Surakarta. Populasi diambil dari mahasiswa di Desa Karang Asem, Kecamatan Laweyan, Kota Surakarta yang memenuhi kriteria restriksi untuk subjek penelitian. Kriteria restriksi yaitu mahasiswa baik pria maupun wanita bukan dari jurusan kesehatan yang tinggal di Desa Karang Asem selama lebih dari 3 bulan dan bersedia dilakukan wawancara dan pemeriksaan. Pengambilan sampel menggunakan metode non random sampling dengan teknik purposive sampling 
yang didasari pada pertimbangan tertentu yang telah memenuhi kriteria inklusi yang ditetapkan peneliti. Berdasarkan pertimbangan tersebut maka dalam penelitian diperoleh sampel sebanyak 43 responden. Variabel bebas dalam penelitian ini adalah tingkat pengetahuan dan perilaku PSN DBD yang diperoleh dari kuesioner sedangkan sebagai variabel terikat adalah keberadaan jentik Aedes aegypti yang diperoleh dari pemeriksaan observasi dengan check list. Teknik analisis data menggunakan uji statistik spearman.

\section{HASIL DAN PEMBAHASAN}

Penelitian ini menggunakan kuesioner tingkat pengetahuan dan perilaku yang diberikan kepada mahasiswa yang tinggal di Desa Karang Asem, Kecamatan Laweyan, Kota Surakarta pada bulan Desember 2016 sampai dengan Januari 2017. Subjek penelitian sebanyak 43 responden yang mana responden tersebut telah memenuhi kriteria inklusi dan eksklusi.

Tabel 1. Distribusi responden berdasarkan tingkat pengetahuan tentang PSN DBD

\begin{tabular}{cccc}
\hline & & N & Persentase \\
\hline \multirow{2}{*}{ Tingkat } & Buruk & 18 & 41,9 \\
Pengetahuan & Baik & 25 & 58,1 \\
& Total & 43 & 100,0 \\
\hline
\end{tabular}

(Sumber: Data Primer, 2017)

Berdasarkan Tabel 1 diketahui bahwa distribusi data responden berdasarkan tingkat pengetahuan didapatkan tingkat pengetahuan yang baik sebesar 25 responden $(58,1 \%)$ sedangkan tingkat pengetahuan yang buruk sebanyak 18 responden $(41,9 \%)$.

Tabel 2 Distribusi responden berdasarkan perilaku PSN DBD

\begin{tabular}{cccc}
\hline \multirow{4}{*}{ Perilaku } & & N & Persentase \\
\hline & Buruk & 20 & 46,5 \\
& Baik & 23 & 53,5 \\
& Total & 43 & 100,0 \\
\hline
\end{tabular}

(Sumber: Data Primer, 2017)

Berdasarkan Tabel 2 diketahui bahwa distribusi data responden berdasarkan perilaku didapatkan perilaku yang baik sebesar 23 responden $(53,5 \%)$ sedangkan perilaku yang buruk sebanyak 20 responden (46,5\%).
Tabel 3 Distribusi responden berdasarkan keberadaan jentik

\begin{tabular}{cccc}
\hline & & N & Persentase \\
\hline \multirow{3}{*}{ Keberadaan } & Negatif & 29 & 67,4 \\
Jentik & Positif & 14 & 32,6 \\
& Total & 43 & 100,0 \\
\hline
\end{tabular}

(Sumber: Data Primer, 2017)

Berdasarkan Tabel 3 diketahui bahwa distribusi data responden berdasarkan keberadaan jentik didapatkan keberadaan jentik yang negatif sebesar 29 responden (67,4\%) lebih besar dibandingkan keberadaan jentik yang positif sebanyak 14 responden $(32,6 \%)$.

Analisis bivariat ini menguraikan hubungan variabel independen dan variabel dependen. Variabel independen adalah tingkat pengetahuan dan perilaku mahasiswa dan variabel dependen yaitu keberadaan jentik Aedes aegypti menggunakan uji statistik Spearman.

Hasil bivariat responden yang mempunyai tingkat pengetahuan baik dengan keberadaan jentik negatif yaitu sebesar 18 responden $(41,9 \%)$ sedangkan responden yang mempunyai tingkat pengetahuan baik dengan keberadaan jentik positif sebanyak 7 responden $(16,3 \%)$, tingkat pengetahuan buruk dengan keberadaan jentik negatif sebanyak 11 responden $(25,6 \%)$, dan tingkat pengetahuan buruk dengan keberadaan jentik positif sebanyak 7 responden (16,3\%). Hasil uji statistik Spearman menunjukkan tidak ada hubungan tingkat pengetahuan dengan keberadaan jentik dengan hasil $\rho=0,464$.

Hasil bivariat responden dengan tingkat perilaku baik dengan keberadaan jentik negatif yaitu sebesar 19 responden (44,2\%) lebih besar jika dibandingkan dengan responden tingkat perilaku baik dengan keberadaan jentik positif sebanyak 4 responden $(9,3 \%)$, tingkat perilaku buruk dengan keberadaan jentik negatif sebanyak 10 responden $(23,3 \%)$ dan tingkat perilaku buruk dengan keberadaan jentik positif sebanyak 10 responden (23,3\%). Hasil uji statistik Spearman menunjukkan ada hubungan tingkat perilaku dengan keberadaan jentik dengan hasil $\rho=0,023$.

Sebanyak 43 responden yang merupakan subjek penelitian ini merupakan mahasiswa aktif yang tinggal di Desa Karang Asem. Sebagian besar responden adalah mahasiswa Universitas Muhammadiyah Surakarta dan Akademi Teknik 
Mesin IndustriSurakarta. Penelitian telah dilakukan di Desa Karang Asem Kecamatan Laweyan Kota Surakarta untuk mengetahui hubungan tingkat pengetahuan dan perilaku mahasiswa tentang PSN DBD terhadap keberadaan jentik Aedes aegypti. Hasil penelitian menunjukkan hubungan yang tidak signifikan antara tingkat pengetahuan dengan keberadaan jentik, sedangkan hubungan tingkat perilaku terhadap keberadaan jentik menunjukkan hasil yang signifikan. Hal ini serupa dengan penelitian oleh Al Richs Nasir, Erniwati Ibrahim, dan Syamsuar Manyullei (2014) bahwa tingkat pengetahuan tidak berpengaruh secara signifikan terhadap tingkat kepadatan larva atau jentik nyamuk yang ada di wilayah Kota Makassar, penelitian tersebut menghasilkan data responden 40 orang $(21,5 \%)$ memiliki tingkat pengetahuan kurang dengan tingkat kepadatan larva tinggi dan hanya 1 orang $(2,4 \%)$ yang memiliki tingkat pengetahuan cukup dengan tingkat kepadatan larva tinggi $\rho=0,309$. Kesimpulan penelitian tersebut menyatakan tidak ada hubungan antara tingkat pengetahuan dengan tingkat kepadatan larva Aedes aegypti di Kota Makassar (Nasir, Ibrahim, \& Manyullei, 2014).

Pada penelitian ini 43 responden tersebut didapatkan tingkat pengetahuan baik tentang PSN DBD dengan keberadaan jentik negatif sebanyak 18 responden (41,9\%) lebih besar jika dibandingkan dengan responden tingkat pengetahuan baik dengan keberaaan jentik positif sebanyak 7 responden (16,3\%), tingkat pengetahuan buruk dengan keberadaan jentik negatif sebanyak 11 responden $(25,6 \%)$ dan tingkat pengetahuan buruk dengan keberadaan jentik positif sebanyak 7 responden (16,3\%). Hasil uji statistik Spearman menunjukkan tidak ada hubungan tingkat pengetahuan dengan keberadaan jentik dengan hasil $\rho=0,464$ ( $\rho>$ $0,05)$ berarti tidak ada hubungan antara tingkat pengetahuan PSN DBD dengan keberadaan jentik Aedes aegypti di Desa Karang Asem Kecamatan Laweyan Kota Surakarta. Dengan kata lain bahwa tidak terdapat korelasi tingkat pengetahuan PSN DBD terhadap keberadaan jentik Aedes aegypti meskipun responden tersebut memiliki tingkat pengetahuan yang baik, belumlah menjadi jaminan bahwa tempat tinggal responden bersih akan keberadaan jentik nyamuk atau pun sebaliknya.

Adapun faktor yang sering mengakibatkan banyaknya keberadaan jentik yaitu lingkungan, manusia, dan sarana dan prasarana yang kurang baik seperti kebanyakan yang ditemukan pada saat observasi adalah cuaca yang sering mengalami hujan mengakibatkan banyaknya genangan air yang cocok untuk vektor nyamuk bertelur serta kepadatan penduduk dalam suatu permukiman yang membuat nyamuk dapat berpindah dari satu tempat ke tempat lain. Tempat penampungan air yang tidak ada penutup dan ketersediaan abate yang masih sedikit, sering ditemukan pada saat observasi di mana hal itu adalah salah satu faktor keberadaan jentik yang ada di sekitar Desa Karang Asem ditemukan. Besarnya penampungan dan lamanya air tertampung mengakibatkan banyaknya nyamuk bertelur, oleh karena itu perilaku seorang individu sangat penting sekali dalam menjaga lingkungan agar meminimalisasi vektor penyakit yang ada di sekitar.

Perilaku tersebut sesuai dengan hasil penelitian yang dilakukan, di mana dari 43 responden tersebut tingkat perilaku baik dengan keberadaan jentik negatif yaitu sebesar 19 responden $(44,2 \%)$ lebih besar jika dibandingkan dengan responden tingkat perilaku baik dengan keberadaan jentik positif sebanyak 4 responden $(9,3 \%)$, tingkat perilaku buruk dengan keberadaan jentik negatif sebanyak 10 responden $(23,3 \%)$, dan tingkat perilaku buruk dengan keberadaan jentik positif sebanyak 10 responden (23,3\%). Hasil uji statistik Spearman menunjukkan hasil $\rho=0,023$ $(\mathrm{p}<0,05)$ maka terdapat hubungan antara tingkat perilaku PSN DBD dengan keberadaan jentik Aedes aegypti di Desa Karang Asem Kecamatan Laweyan Kota Surakarta. Penelitian Booroto pada tahun 2012 menunjukkan hal yang sama di mana responden dengan perilaku buruk dan positif terdapat jentik sebesar $70,3 \%$, sedangkan responden dengan perilaku baik dan positif terdapat jentik sebesar $28,26 \%$ penelitian tersebut didapatkan $\rho=0,037$ yang artinya nilai tersebut lebih kecil daripada $\rho<0,05$ yang berarti adanya hubungan perilaku PSN dan keberadaan jentik.

Hal tersebut disebabkan responden hanya membersihkan tempat penampungan air yang dapat dijangkau saja, padahal perilaku PSN adalah membersihkan tempat penampungan air di semua tempat agar memperkecil tempat perkembangbiakan nyamuk Aedes aegypti (Azlina, adrial, \& anas, 2016). Perilaku PSN DBD yang masih kurang baik menunjukkan bahwa kurangnya kesadaran individu dalam pentingnya 
menjaga kebersihan rumah dan lingkungan sekitar tempat tinggal agar dapat mencegah penyakit DBD. Notoatmodjo (2007) menyebutkan bahwa perilaku masyarakat mempunyai pengaruh terhadap lingkungan karena lingkungan merupakan lahan untuk perkembangan perilaku tersebut. Kurang atau baiknya perilaku PSN DBD individu akan menentukan lingkungan yang kondusif atau pun tidak bagi perkembangan nyamuk Aedes aegypti.

\section{SIMPULAN}

Dari penelitian ini dapat diambil kesimpulan sebagai berikut:

1. tidak ada hubungan tingkat pengetahuan dengan keberadaan jentik.

2. ada hubungan tingkat perilaku dengan keberadaan jentik.

\section{DAFTAR PUSTAKA}

Azlina, A., Adrial, \& Anas, E. 2016. Hubungan tindakan Pemberantasan Sarang Nyamuk dengan Keberadaan Larva Vektor Nyamuk DBD di Kelurahan Lubuk Buaya. Jurnal Kesehatan Andalas, 1, 221-227.

Chen, K., Suhendro, Nainggolan, L., \& Pohan, H. (2006). Demam Berdarah Dengue. In Buku Ajar Ilmu Penyakit Dalam p. 1709. Jakarta: Departemen Ilmu Penyakit dalam Fakultas Kedokteran Universitas Indnesia.

DINKES. 2012. Buku Profil Kesehatan Jawa Tengah. Semarang: DINKES .

DINKES. 2012. Peraturan Bupati Malang nomor 2 tentang Pengendalian Penyakit Demam Berdarah Dengue di Kabupaten Malang. Malang: Dinas Kesehatan Kabupaten Malang.

KEMENKES. 2010. Demam Berdarah Dengue. Buletin Jendela Epidemiologi, II, 22.

KEMENKES. 2011. Modul Pengendalian Demam Berdarah Dengue. Jakarta: Kementerian Kesehatan Republik Indonesia.

KEMENKES. 2012. Pedoman Pengendalian Demam Chikungunya (2nd ed.). Jakarta: Kementrian Kesehatan Republik Indonesia.

KEMENKES. 2012. Petunjuk Teknis Pemberantasan Sarang Nyamuk Demam Berdarah Dengue (PSN DBD) oleh juru pemantau jentik (Jumantik). Jakarta: Kementrian Kesehatan Republik Indonesia.

KEMENKES. 2012. Profil Kesehatan Indonesia. Jakarta: KEMENKES.

Notoatmodjo, S. 2007. Promosi Kesehatan dan Ilmu Perilaku. Jakarta: Rineke Cipta.

Suharti, S. 2010. Tesis. Hubungan Pengetahuan dan Motivasi dengan Perilaku Kepala Keluarga dalam Pemberantasan Sarang Nyamuk Demam Berdarah Dengue (di Wilayah Kerja Puskesmas Loa Ipuh Kabupaten Kutai Kartanegara).

WHO. 2016. Dengue and Severe Dengue. Dipetik November 6, 2016, dari http://www.who.int 